\title{
Los patriotas en escena (1862-1869)
}

Juan de Dios Barrueta Rath (10 https://orcid.org/0000-0002-0543-3011

Doctorado en Historia

CIESAS-Peninsular, México

jddrathciesasdoc@gmail.com

Miguel Ángel Vásquez Meléndez, Los patriotas en escena (1862-1869), México, El Colegio de México, 2018, 159 pp. ISBN 9786076282434.

Con Los patriotas en escena, el autor estudia las relaciones entre el teatro y la historia política de México entre 1862 y 1869. El libro se divide en cuatro partes. En la primera, titulada “Manuscritos y PDF”, el autor describe las fuentes a las que recurrió para hacer su investigación y advierte de la complejidad inherente al estudio de la historia del teatro mexicano, debido a que los archivos se encuentran dispersos en colecciones privadas y públicas, sin que se hayan podido integrar aún en corpus unitarios.

Las fuentes a que acude Vásquez son las obras teatrales propiamente, las crónicas y noticias de representaciones aparecidas en archivos hemerográficos y la imprescindible obra del crítico madrileño Enrique de Olavarría y Ferrari, Reseña histórica del teatro en México.

Entre las obras teatrales, el autor selecciona tres para estudiarlas a detalle:

1. El embrollo mexicano, ¿cuál será el fin de la comedia? (1862). Hallazgo fortuito de una pieza de solamente dos páginas, citada del diario parisino Charivari, traducida por 
Francisco G. Flores, en una publicación periódica mexicana llamada El palo de ciego, periódico poco político de costumbres, literatura, variedades y avisos.

2. Mi amor, bandera y laurel; o sea, la enseña nacional (1869) de Mariano Eduardo Ramos.

3. Loa patriótica en un acto y en verso (1869) de Justo Sierra, Enrique de Olavarría y Esteban González.

Las obras mencionadas fueron halladas en periódicos y revistas de la época, que el autor encontró en las bibliotecas del Instituto Mora, la Biblioteca Nacional de la UNAM y el AGN. La importancia de estas fuentes está en la fuerte conexión que el teatro, como práctica social ligada a la vida cotidiana de las masas, tuvo con los acontecimientos histórico-políticos, en una coyuntura especialmente álgida durante los años que van de la instauración del segundo imperio mexicano a la restauración de la república.

En la segunda parte del libro titulada "Episodios de historia teatral", Vásquez profundiza en la descripción del ambiente cultural y político que se vivía en la época. A lo largo del texto el lector advertirá continuidades en las costumbres que el México independiente heredó del régimen colonial en diversos aspectos de la vida cotidiana, especialmente en lo que se refiere a conmemoraciones públicas, actos oficiales, diversiones y representaciones teatrales. El autor nos habla también de los espacios de representación. De la época virreinal, nos dice, quedaron en pie el antiguo Coliseo de comedias, llamado desde 1826 Teatro Principal, así como la Alameda Central y el Palenque de gallos, que se mantuvieron como espacios populares. No obstante, la conformación de la nación independiente requirió de espacios monumentales de representación y, para 1842, el empresario teatral Francisco Arbeu, -con apoyo del presidente Santa Anna- promovió la construcción del Gran Teatro de Santa Anna, 


\section{Juan de Dios Barrueta Rath}

el cual, tras las derrotas y el desprestigio sufridos por el caudillo, pasó a nombrarse Gran Teatro Nacional. Luego, con la instauración del segundo imperio, se llamó Gran Teatro Imperial y nuevamente Gran Teatro Nacional, tras la restauración republicana.

1862 fue un año clave, pues Benito Juárez y su grupo político intentaban mantenerse en el poder, mientras que los conservadores hacían gestiones para entregar el gobierno a un príncipe extranjero. Ambos, liberales y conservadores, recurrieron al teatro como escenario de propaganda. Los liberales, de pensamiento nacionalista, contaban con autores como Vicente Riva Palacio, quien además de exitoso poeta dramático y empresario teatral fue un destacadísimo militar y político liberal. Junto a Juan A. Mateos, Riva Palacio realizó exitosas temporadas teatrales desde 1861, con títulos como Odio hereditario, (historias de amores imposibles entre amantes pertenecientes a familias opuestas políticamente), El abrazo de Acatempan, (premiada en los festejos del 16 de septiembre), Temporal y eterno, La política casera, La catarata del Niágara (Un veterano de la guerra contra los norteamericanos, mutilado como el país, es capaz aún de defenderse de los extranjeros). Las temporadas regulares se complementaban con funciones a beneficio de viudas y huérfanos de las guerras entre liberales y conservadores, y los temas iban desde la franca propaganda nacionalista y xenófoba hasta los eventuales llamados a la reconciliación. Los autores de moda: Riva Palacio y Mateos, Guillermo Prieto y Alfredo Chavero. Todo ese año de 1862 fue de intensa actividad teatral y política. Un teatro de propaganda y agitación patriótica nacionalista. Sin embargo, para 1863, los liberales tuvieron que dejar la capital en manos de los franceses y el panorama teatral hubo de tomar un giro al que los empresarios y actores no tuvieron más remedio que adaptarse. El ahora Gran Teatro Imperial, bajo la dirección del poeta dramático español José Zorrilla, fue el nuevo episodio teatral de esa década. 
En la tercera parte del libro, titulada "La República en tres actos", el autor se concentrará en el análisis de las obras seleccionadas como su objeto de estudio y en la importancia de cada una como dispositivo de propaganda a favor del pensamiento liberal nacionalista y restaurador de la República.

El embrollo mexicano, de 1862, publicada originalmente en el diario parisino Charivari, resulta especialmente reveladora, pues evidencia en su trama el anacronismo de la tentativa imperial mexicana. Muestra a un príncipe frívolo, dispuesto a hacer justo lo que Maquiavelo hubiera contraindicado. Recibir un imperio conquistado por potencias extranjeras y especialmente por una Francia que, poco menos de un siglo antes, había formulado los modernos ideales republicanos de libertad de los pueblos y las naciones. El final mostraba a un archiduque desilusionado y resignado a desistir de su insensato empeño.

Mi amor, bandera y laurel de 1869 propone una historia de patriótica resistencia y lucha. Un esposo fiel, quien va a la guerra a defender a la patria y cuya esposa borda una bandera nacional para su amado. Es también un llamado a integrarse a las tropas liberales, encendiendo la llama del patriotismo. El análisis de Vásquez considera los símbolos que representa cada personaje en la construcción de los ideales republicanos de familia y sociedad. Los modelos son, desde luego, Juárez y Margarita Maza, como lo fueron para los conservadores Miramón y Conchita Lombardo, a través de su romántico epistolario.

La Loa Patriótica de 1869 acude, como las loas barrocas que precedían a los autos sacramentales, a personajes alegóricos, pero en este caso, se trata de La Patria, dama respetable y venerada; El Pueblo mexicano, al principio soñoliento, pero luego bravo defensor; el coro de vicios integrado por La Traición, La guerra y El hambre, quienes encarnan las cualidades de los conservadores, mientras que el coro de virtudes, entre las cuales se halla nada menos 


\section{Juan de Dios Barrueta Rath}

que La Reforma liberal, encarnan las cualidades de los liberales. La patria es raptada y su hijo, el Pueblo Mexicano, es despertado de su sueño por las virtudes para que se disponga a rescatar a su madre. Las virtudes le indican también que, para lograrlo, tendrá que empuñar la espada. El Pueblo se alista al combate y la Historia aparece ante la Patria y se reconocen los triunfos ancestrales del Pueblo Mexicano, anteriores a la conquista.

La prolongada estancia de los liberales en el poder permitió la difusión y arraigo en el imaginario popular de sus principios nacionalistas, apoyados por temporadas teatrales regulares y a beneficio de víctimas de las guerras.

En la parte cuatro, titulada “Teatro e historia”, el autor concluye con reflexiones acerca del entrecruzamiento que se dio entre la historia teatral mexicana y la historia política. El periodo entre 1862 y 1869 resulta idóneo para estudiar a fondo esas relaciones pues ante la imposición de un gobierno extranjero surgieron obras nacionalistas, afines al ideario liberal. El afianzamiento de prácticas conmemorativas y recreaciones nacionalistas acude también a una continuidad con las costumbres heredadas de la época colonial, en la cual se celebraban conmemoraciones como la toma de Tenochtitlan por Cortés, la jura de los virreyes, el nacimiento de un heredero o la unción de un obispo.

Considero esta obra de Miguel Ángel Vásquez una interesante contribución a la historia del teatro mexicano, por destacar la importancia e influencia de las representaciones teatrales en tanto que dispositivo de formación política y propaganda, en momentos álgidos de la historia política de México. Las obras seleccionadas, además, permiten entender la propuesta del autor en lo relativo a que el teatro es una fuente tan importante como las novelas históricas para el estudio de la vida cotidiana durante la formación del Estado Nación. Acaso la naturaleza efímera del fenómeno escénico haya sido un obstáculo para integrar un archivo 
unitario de la historia del teatro mexicano, que permita su viabilidad como fuente para el estudio de la vida cotidiana. Sin embargo, estudios como el presente, permiten abrigar cierto optimismo acerca de lo que se puede hallar en los textos teatrales y en las crónicas de espectáculos, en revistas y periódicos, en los diarios personales de artistas, intelectuales, políticos, empresarios y personas comunes. La cabal comprensión respecto de procesos históricos complejos, no puede prescindir de un enfoque próximo al gusto humano, a la vida cotidiana, así como al ejercicio y goce de prácticas culturales. 